\title{
The Influence of Seed Rate and Inter-Row Spacing on Seed Yield and Yield Attributes of Black Cumin in Arsi Highlands, Ethiopia
}

\author{
Fekadu Gebretensay Mengistu $^{1 *} \quad$ Gizaw Wegayehu ${ }^{2} \quad$ Demis Fikre $^{2}$ Awoke Ali $^{2}$ \\ Dasta Tsagaye ${ }^{2}$ Nimona Fufa ${ }^{2}$ \\ 1.Horticulture Research Department, Debrezeit Agricultural Research Center, Ethiopian Institute of Agriculture \\ Research, PO box 32, Debrezeit, Ethiopia \\ 2.Horticulture Research Department, Kulumsa Agricultural Research Center, Ethiopian Institute of Agriculture \\ Research, PO box 489, Kulumsa, Ethiopia
}

\begin{abstract}
Black cumin is the major and the most important spice in Southeast highlands of Ethiopia. However, the yield of the crop is very low mainly due to lack of optimum plant density. A field experiment was done with the objective to assess the influence of different seed rates and inter-row spacing on yield and yield attributes of black cumin at Kulumsa. This experiment was done in the cropping years of 2017, 2018 and 2019 at Kulumsa Agricultural Research Center, Southeast Ethiopia. Twelve treatment combinations of four seed rates $\left(5 \mathrm{~kg} \mathrm{ha}^{-1}, 10 \mathrm{~kg} \mathrm{ha}^{-1}, 15\right.$ $\mathrm{kg} \mathrm{ha}^{-1}$ and $\left.20 \mathrm{~kg} \mathrm{ha}^{-1}\right)$ and three inter-row spacing $(20 \mathrm{~cm}, 30 \mathrm{~cm}$ and $40 \mathrm{~cm})$ were studied on a black cumin variety - 'Aden', which was laid out in a randomized complete block design (RCBD) with factorial arrangement in three replications. The interaction effect of seed rate and inter-row spacing was not statistically significant $(\mathrm{P}>$ $0.05)$ on all growth and yield parameters. However, the main effect of seed rate was significant $(\mathrm{P}<0.05)$ on most of the parameters studied while inter-row spacing was significant only on days to emergence and plant height. Yield and yield attributing factors such as number of primary branch plant ${ }^{-1}$, number of secondary branch plant ${ }^{-1}$, number of pods plant ${ }^{-1}$ and seed yield ha ${ }^{-1}(\mathrm{~kg})$ were significantly influenced by the seed rate. Seed yield increased from $462 \mathrm{~kg} \mathrm{ha}^{-1}$ to $634 \mathrm{~kg} \mathrm{ha}^{-1}$ as seed rate increased from $5 \mathrm{~kg} \mathrm{ha}^{-1}$ to $20 \mathrm{~kg} \mathrm{ha}^{-1}$ and showed a decrease in yield from $601 \mathrm{~kg} \mathrm{ha}^{-1}$ to $507 \mathrm{~kg} \mathrm{ha}^{-1}$ as inter-row spacing increased from $20 \mathrm{~cm}$ to $40 \mathrm{~cm}$ although it was not significant. Hence, $15 \mathrm{~kg} \mathrm{ha}^{-1}$ seed rate and $30 \mathrm{~cm}$ inter-row spacing could be recommended for optimum black cumin production in the study area. However, further research needs to be undertaken in different black cumin producing areas of the country on recent varieties to achieve the optimum seed rate and inter-row spacing with information related to cost of production for better recommendation.
\end{abstract}

Keywords: competition, crop management, Nigella sativa, plant density

DOI: $10.7176 / \mathrm{JBAH} / 11-1-04$

Publication date: January $31^{\text {st }} 2021$

\section{Introduction}

Black cumin (Nigella sativa L.) is an annual seed spice and a medicinal herb belongs to the Ranunculaceae family. Sometimes it is referred to as nigella or black seeds or 'Tiku azmud' in Amharic (Habtewold et al. 2017). This species is originated in Egypt and East Mediterranean, but is widely cultivated in Iran, Japan, China and Turkey (Shewaye Lakew 2011). Ethiopia is among the major black cumin producing and exporting countries like India, Sri Lanka, Bangladesh, Afghanistan, Pakistan, Egypt, Iran, Iraq, Syria and Turkey (Samima et al. 2018). The majority of Ethiopia's black cumin exports go to Arabic and some Muslim countries and it reached to $98 \%$ of the national exports (Orgut 2007). According to Ethiopian Investment Agency Report, Ethiopian annual production of black cumin seed was 18 thousand metric tons in the cropping year of 2015 (EIC 2016).

Black cumin grows as a rain fed crop within 1500 to 2400 meters of altitude on heavy black soils and prefers loamy sand soils (Datta et al. 2001), on soil pH of 7.0 to 7.5 (Orgut 2007). In Ethiopia it has a similar agroecological requirement as teff (Eragrostis tef) and chick pea (Cicer arietinum) and usually cultivated on residual moisture following the latter crops. It is a major crop in Dembia in South Gonder, Shirka in Arsi Zone and Goro in Bale Zone (Alemaw et al. 2010).

In addition to its use for spice and culinary purposes, black cumin has multiple uses in cosmetic as well as medicinal industries (Ali \& Blunden 2003; Arici et al. 2005; Black et.al. 2005; Kokdil et al. 2005; Kokdil et al. 2006; Ashraf \& Orooj 2006). In Ethiopia, it is commonly used to make 'Berbere' for the preparation of traditional Ethiopian stews such as 'wot' and preservation of butter. It is principally used to flavor food, either as whole grain, in powdered form or as an oleoresin extract (Hedberg et al. 2003).

The national average productivity of black cumin was reported to be $0.79 \mathrm{t} \mathrm{ha}^{-1}$ (Kifelew et al. 2017); while Zigyalew Gashaw (2020) reported $0.64 \mathrm{t} \mathrm{ha}^{-1}$, which is well below the global average and some major producing countries such as India $\left(2.2 \mathrm{t} \mathrm{ha}^{-1}\right)$. However, high seed yield of up to $1.7 \mathrm{tha}^{-1}$ at Adet and $1.8 \mathrm{tha}^{-1}$ at Woreta were obtained (Adam Abebe 2006). The low yields are mainly due to the low productivity of the varieties (Ermias Assefa et al. 2015) and the poor agronomic practices used by the farmers (Hammo 2008). Among the factors, suitable planting density play the major role to affect crops' yield and agronomists believe that the establishment 
of optimum density for a given crop plant in a field is the basis for the successful cropping that could boost the productivity. Optimum plant density is a density at which all environmental factors including water, air, light, soil etc. are fully exploited by the plants and at the same time, intra-species and extra-species competitions are minimized (Alizadeh \& Koucheki 1995). Black cumin lacks research recommendations on optimum plant density (seed rate) and row spacing that could lead to the poor yield of the crop. Hence, it is vital to identify the suitable seed rates and row spacing for black cumin production. Therefore, this study was initiated with the objective of finding out the optimum seed rate and inter- row spacing for better growth and yield attributes of black cumin.

\section{Materials and methods}

2.1 Description of the study area

The study was conducted at Kulumsa Agricultural Research Center (KARC) in the main growing season of 2017, 2018 and 2019 located at $8^{\circ} 00^{\prime}$ to $8^{\circ} 02^{\prime} \mathrm{N}$ latitude and $39^{\circ} 07^{\prime}$ to $39^{\circ} 10^{\prime} \mathrm{E}$ longitude at an elevation of 2210 m.a.s.l in Tiyo District, Arsi Administrative Zone of the Oromia Regional State, $167 \mathrm{~km}$ Southeast of Addis Ababa. It is located on a very gently undulating topography with a gradient of 0 to $10 \%$ slope (Abayneh et al. 2003). The agro-climatic condition of the area is wet with $832 \mathrm{~mm}$ mean annual rain fall and has a uni-modal rainfall pattern with extended rainy season from March to September while the peak season is from June to August. The mean annual maximum and minimum temperatures are 23.2 and $10^{\circ} \mathrm{C}$, respectively and has three major soil types: EutricVertisol, VerticLuvisol and VerticCambisol (Abayneh et al. 2003).

\subsection{Experimental materials, design and treatments}

The experiment was carried out using a popular black cumin variety 'Aden', which was released by Ethiopian Institute of Agriculture Research (EIAR), Melkasa Agricultural Research Center (MARC) (MoANR 2009). 'Aden' is a widely popularized and cultivated variety with a yield potential of up to $1.5 \mathrm{t} \mathrm{ha}^{-1}$ under research management and 0.8 to $1.2 \mathrm{t} \mathrm{ha}^{-1}$ under farmers' management (Alemaw et al. 2010, Table 1). Two factors were included in the experiment namely four seed rates $\left(5 \mathrm{~kg} \mathrm{ha}^{-1}, 10 \mathrm{~kg} \mathrm{ha}^{-1}, 15 \mathrm{~kg} \mathrm{ha}^{-1}\right.$ and $\left.20 \mathrm{~kg} \mathrm{ha}^{-1}\right)$ and three inter-row spacing $(20$ $\mathrm{cm}, 30 \mathrm{~cm}$ and $40 \mathrm{~cm}$ ) which were combined into twelve treatments. Each experimental plot measured $4.32 \mathrm{~m}^{2}$ and the number of planted rows per plot varied accordingly based on the inter-row spacing treatments (12,8 and 6 rows for $20 \mathrm{~cm}, 30 \mathrm{~cm}$ and $40 \mathrm{~cm}$ row-spacing respectively). Each treatment was assigned to the experimental plots using Randomized Complete Block Design (RCBD) in three replications. All agronomic practices including (fertilization, pest management, cultivation etc.) except seed rate and row-spacing were applied uniformly to each experimental unit as recommended.

Table 1. Description of the black cumin variety (Aden) used in the present study

\begin{tabular}{|c|c|c|c|c|c|c|c|c|}
\hline \multirow[t]{2}{*}{ Variety } & \multicolumn{2}{|r|}{ Release } & \multirow[t]{2}{*}{$\begin{array}{l}\text { Altitude } \\
\text { (masl) }\end{array}$} & \multirow[t]{2}{*}{$\begin{array}{l}\text { Maturity } \\
\text { (days) }\end{array}$} & \multicolumn{2}{|c|}{$\begin{array}{l}\text { Productivity } \\
\left(\text { t ha }^{-1}\right)\end{array}$} & \multirow[t]{2}{*}{$\begin{array}{c}\text { Oleoresin } \\
(\%)\end{array}$} & \multirow[t]{2}{*}{$\begin{array}{c}\text { Essential } \\
\text { Oil (\%) }\end{array}$} \\
\hline & Year & ${ }^{1}$ Breeder & & & Research & Farmer & & \\
\hline Aden & 2009 & MARC/EIAR & $\begin{array}{l}1500- \\
2400\end{array}$ & $134-150$ & 1.5 & $0.8-1.2$ & $27.2-32.4$ & $0.6-1.2$ \\
\hline
\end{tabular}

${ }^{1}$ MARC: Melkasa Agricultural Research Center, EIAR: Ethiopian Institute of Agricultural Research, Source:

(Alemaw et al. 2010)

\subsection{Parameters and data collection}

Data for different parameters were collected from the middle rows of the experimental plots and five randomly selected plant samples per plot were used to make plant based measurements. Days to emergence (DE), Days to $50 \%$ flowering (DF), Days to maturity (DM), Plant height (PH), Number of primary branch per plant (NPB), Number of secondary branch per plant (NSB), Number of pod per plant (NPDPP), Number of seed per pod (NSPPD), Seed yield per pant (SYLDPP) and Seed yield per hectare (SYLDHA) were the parameters for which data were collected for this study.

Data for the aforementioned parameters were subjected to Analysis of Variance (ANOVA) using SAS Statistical Package Program (SAS 2009). The significant differences among treatment means were compared using the Least Significant Difference Test (LSD) at 5\% probability level.

\section{Results}

ANOVA revealed that the interaction effects of seed rate and inter-row spacing was not obtained on any of the parameters studied (Table 2). However most of the parameters including days to emergence, plant height $(\mathrm{cm})$, number of primary branch per plant, number of secondary branch per plant, number of pods per plant, and seed yield per hectare were significantly affected by the main effect of the seed rate $(\mathrm{P}<0.05)$. In contrary, days to $50 \%$ flowering, days to maturity, number of seeds per pod and seed yield per plant were not significantly affected by the seed rate $(\mathrm{P}>0.05)$. However, inter-row spacing affected only days to emergence and plant height.

Days to emergence was not significantly changed when the seed rate varied from 5 to $15 \mathrm{~kg} \mathrm{ha}^{-1}$, however it 
started to increase when the seed rate increased to $20 \mathrm{~kg} \mathrm{ha}^{-1}$ (Table 2). The higher the seed rate the longer the time the seed took to emerge from the soil and the lower the seed rate the earlier the emergence (Figure $1, \mathrm{r}^{2}=0.94$ ). Likewise, the inter-row spacing significantly affected days to emergence (Table 2). The narrow the spacing the late the emergence, while the wider the spacing the earlier it became (Figure $1, \mathrm{r}^{2}=0.91$ ). Plant height was also significantly affected by the main effects of the seed rate and inter-row spacing (Table 2). When the seed rate increased, plant height was also increased and vice versa (Figure $1, \mathrm{r}^{2}=0.76$ ); while when the inter-row spacing became wider, plant height was highly reduced (Figure $1, \mathrm{r}^{2}=0.97$ ). Conversely, increasing the seed rate significantly reduced the number of primary branches per plant (Figure 2, $\mathrm{r}^{2}=0.67$ ) as well as the number of secondary branches per plant (Figure $2, \mathrm{r}^{2}=0.50$ ). Likewise, the number of pods per plant was also reduced with increasing the seed rate from 5 to $20 \mathrm{~kg} \mathrm{ha}^{-1}$. However, the seed yield per hectare increased significantly with increased seed rate with no point of return (Table 2).

Table 2. Effect of seed rate and inter-row spacing on seed yield and yield attributes of Black cumin

\begin{tabular}{|c|c|c|c|c|c|c|c|c|c|c|}
\hline Treatments & DE & DF & DM & $\begin{array}{l}\text { PH } \\
(\mathrm{cm})\end{array}$ & NPB & NSB & $\begin{array}{l}\text { NPD } \\
\text { PP }\end{array}$ & $\begin{array}{l}\text { NSP } \\
\text { PD }\end{array}$ & $\begin{array}{l}\text { SYLDPP } \\
\text { (g) }\end{array}$ & $\begin{array}{l}\text { SYL } \\
\text { DHA } \\
\text { (kg) }\end{array}$ \\
\hline \multicolumn{11}{|c|}{ Seed Rate $\left(\mathrm{kg} \mathrm{ha}^{-1}\right)$} \\
\hline 5 & $19.52^{\mathrm{a}}$ & 93.07 & 153.56 & $74.23^{b}$ & $5.56^{\mathrm{a}}$ & $19.53^{\mathrm{a}}$ & $25.10^{\mathrm{a}}$ & 94.23 & 2.68 & $462^{b}$ \\
\hline 10 & $19.33^{\mathrm{a}}$ & 93.00 & 154.18 & $75.41^{\mathrm{ab}}$ & $5.096^{\mathrm{b}}$ & $15.78^{b}$ & $20.62^{\mathrm{b}}$ & 93.94 & 2.29 & $506^{\mathrm{ab}}$ \\
\hline 15 & $18.44^{\mathrm{ab}}$ & 93.18 & 153.78 & $75.00^{\mathrm{ab}}$ & $5.22^{\mathrm{ab}}$ & $17.40^{\mathrm{ab}}$ & $21.76^{\mathrm{b}}$ & 101.01 & 2.65 & $584^{\mathrm{ab}}$ \\
\hline 20 & $18.04^{\mathrm{b}}$ & 92.96 & 153.81 & $76.70^{\mathrm{a}}$ & $5.00^{\mathrm{b}}$ & $15.73^{\mathrm{b}}$ & $20.84^{\mathrm{b}}$ & 96.30 & 2.36 & $636^{\mathrm{a}}$ \\
\hline LSD & 0.45 & 0.69 & 0.86 & 2.38 & 0.36 & 2.48 & 2.80 & 11.21 & 0.42 & 139 \\
\hline Significance & $* *$ & ns & ns & $* *$ & $* *$ & $* *$ & $* *$ & ns & $\mathrm{ns}$ & $* *$ \\
\hline \multicolumn{11}{|c|}{ Inter-Row Spacing (cm) } \\
\hline 20 & $19.03^{\mathrm{a}}$ & 92.69 & 153.78 & $76.62^{\mathrm{a}}$ & 5.13 & 16.84 & 21.70 & 92.47 & 2.49 & 601 \\
\hline 30 & $18.92^{\mathrm{ab}}$ & 93.28 & 153.89 & $75.23^{\mathrm{ab}}$ & 5.33 & 17.71 & 22.78 & 98.74 & 2.43 & 533 \\
\hline 40 & $18.56^{\mathrm{b}}$ & 93.19 & 153.83 & $74.14^{\mathrm{b}}$ & 5.20 & 16.77 & 21.74 & 97.89 & 2.56 & 507 \\
\hline LSD & 0.39 & 0.60 & 0.74 & 2.06 & 0.32 & 2.15 & 2.42 & 9.71 & 0.37 & 120 \\
\hline CV (\%) & 4.26 & 1.33 & 0.99 & 5.63 & 12.46 & 25.85 & 22.58 & 20.70 & 30.22 & 45.20 \\
\hline Significance & $*$ & ns & ns & $*$ & ns & ns & ns & ns & ns & ns \\
\hline
\end{tabular}

Means within a column having the same letters are not significantly different. $*$ - Significant at $5 \%$ level, $* *$ Significant at $1 \%$ level. DE=Days to Emergence, $\mathrm{DF}=$ Days to $50 \%$ flowering, $\mathrm{DM}=$ Days to maturity, $\mathrm{PH}=\mathrm{Plant}$ height, $\mathrm{NPB}=$ Number of primary branch per plant, $\mathrm{NSB}=$ Number of secondary branch per plant, $\mathrm{NPDPP}=$ Number of pod per plant, NSPPD $=$ Number of seed per pod, SYLDPP $=$ Seed yield per pant, and SYLDHA= Seed yield per hectare.
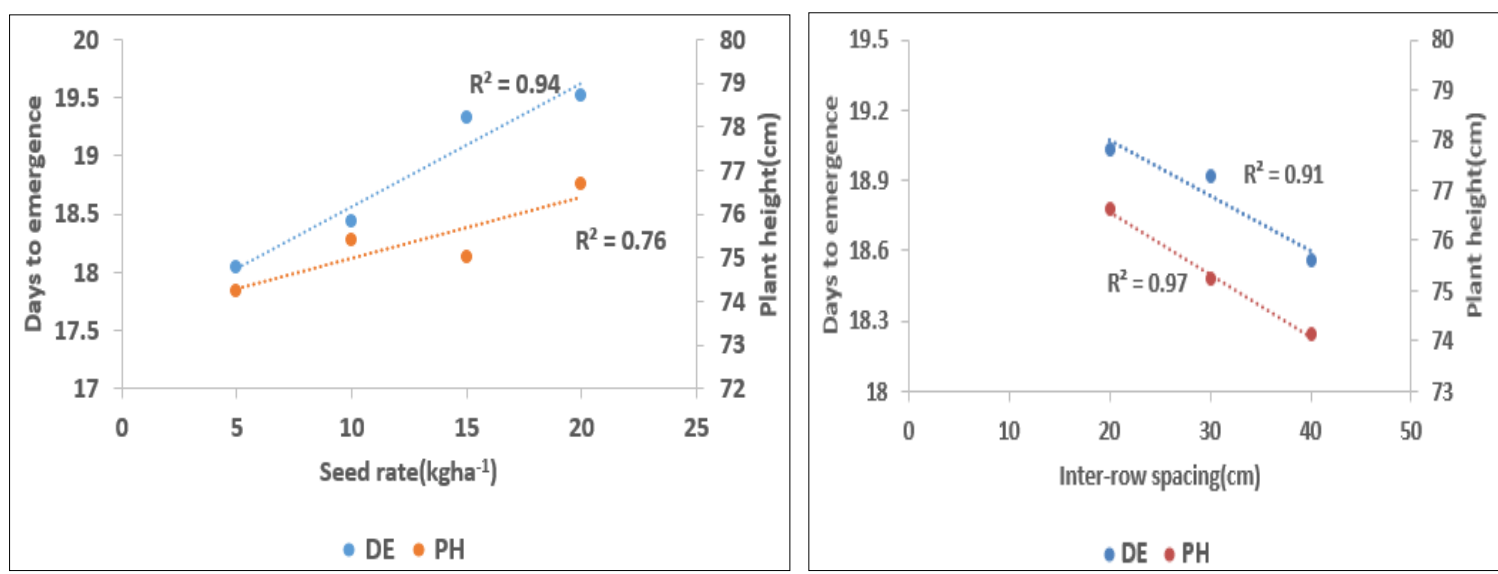

Figure 1. Responses of days to emergence and plant height to seed rate (left) and inter-row spacing (right). $\mathrm{DE}=$ Days to emergence, $\mathrm{PH}=$ Plant height. 

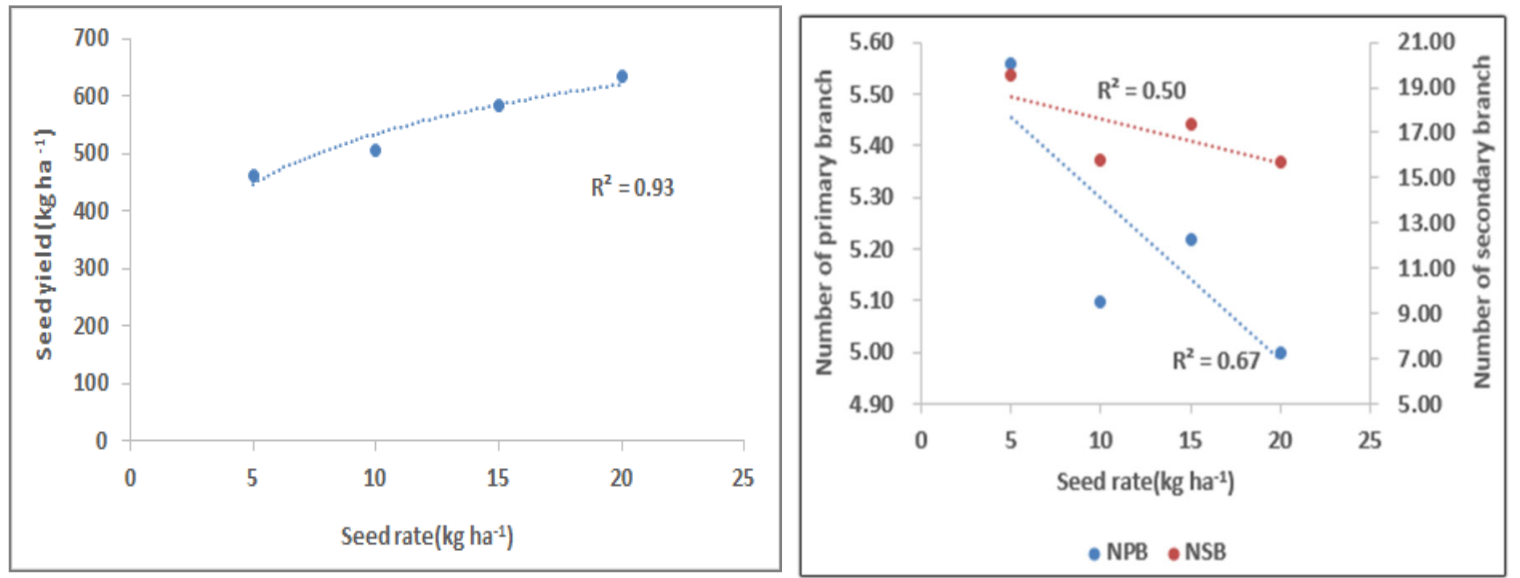

Figure 2. Responses of seed yield (left), and number of primary and secondary branch (right) to seed rate. $\mathrm{NPB}=$ Number of primary branch, $\mathrm{NSB}=$ Number of secondary branch.

\section{Discussion}

The results of the present study showed that plant height was affected by the seed rate and inter-row spacing. The highest seed rate $\left(20 \mathrm{~kg} \mathrm{ha}^{-1}\right)$ and the smallest inter-row spacing $(20 \mathrm{~cm})$ produced the highest average plant heights $(76.70 \mathrm{~cm}$ and $76.62 \mathrm{~cm})$ respectively; while the lowest values $(74.23 \mathrm{~cm}$ and $74.14 \mathrm{~cm})$ were obtained at the lowest seed rate $\left(5 \mathrm{~kg} \mathrm{ha}^{-1}\right)$ and the largest inter-row spacing $(40 \mathrm{~cm})$ respectively (Table 2). The results also affirmed the presence of significant and linear relationship between the seed rate $\left(\mathrm{r}^{2}=0.76\right)$ and inter-row spacing $\left(r^{2}=0.97\right)$ with plant height respectively (Figure 1). These findings on plant height were in accordance with Toncer \& Kizil (2004); Tuncturk et al. (2005) and Roussis et al. (2017) who obtained similar results, although did on a different genotype and environment. Tuncturk et al. (2005) found that an increasing seed rate in black cumin increased plant height; while the highest value $(40.68 \mathrm{~cm})$ was obtained from $15 \mathrm{~kg} \mathrm{ha}^{-1}$ seed rate and the lowest $(34.68 \mathrm{~cm})$ from $10 \mathrm{~kg} \mathrm{ha}^{-1}$. Similarly, Roussis et al. (2017) showed increasing trends in plant heights from 18.9 $\mathrm{cm}$ to $22.7 \mathrm{~cm}$ with increased seed rate from 50 to $60 \mathrm{~kg} \mathrm{ha}^{-1}$, although it is much higher compared to the rates used in the presented study as well as in Tuncturk et al. (2005). Toncer \& Kizil (2004) reported comparable results with the present study in that many of the growth and yield parameters were affected by seed rates in the range of 10 to $40 \mathrm{~kg} \mathrm{ha}^{-1}$; except thousand seed weight and seed number per capsule. The higher seed rates $(40 \mathrm{and} 50 \mathrm{~kg}$ $\mathrm{ha}^{-1}$ ) reduced number of branch, number of capsule per plant, seed yield per plant and seed yield per hectare.

Similar results also reported by Koli (2013), who stated that increasing the plant density of black cumin (higher seed rate and closer inter-row spacing) within an area of land increased plant height, this may be due to higher competition among the plants.

Likewise, the number of branches (both primary and secondary) per plant were influenced by the seed rate. The number of branches per plant decreased with increased seed rate; which varied from 5.56 to 5 (primary branch) and 19.53 to 15.73 (secondary branch) for the increasing seed rate from 5 to $20 \mathrm{~kg} \mathrm{ha}^{-1}$. This finding was also reported in related works of Tuncturk et al. (2005) \& Roussis et al. (2017). In contrary to plant height, the highest values for the number of branches per plant in the present study either for the primary (5.56) or for the secondary (19.53) was due to the lowest seed rate $\left(5 \mathrm{~kg} \mathrm{ha}^{-1}\right)$ used and the lowest values ( 5 and 15.73) however were obtained from the highest seed rate $\left(20 \mathrm{~kg} \mathrm{ha}^{-1}\right)$. In similar fashion, Tuncturk et al. (2005) obtained the highest number of branches (9.56) at the lowest seed rate $\left(5 \mathrm{~kg} \mathrm{ha}^{-1}\right)$ and the lowest branches (6.46) at the highest seed rate $\left(20 \mathrm{~kg} \mathrm{ha}^{-}\right.$ $\left.{ }^{1}\right)$. Roussis et al. (2017) also demonstrated similar result trends although not significant between the seed rates used (50 and $60 \mathrm{~kg} \mathrm{ha}^{-1}$ ). According to K1z1l (2002), when seed rate increased, the number of branches per plant decreased linearly probably due to a higher interplant competition.

The number of pods (capsules) per plant varied between the seed rates with the highest mean value of 25.20 at the lowest seed rate $\left(5 \mathrm{~kg} \mathrm{ha}^{-1}\right)$ and the lowest value (20.62) at the highest seed rate $\left(20 \mathrm{~kg} \mathrm{ha}^{-1}\right)$. The number of pods per plant was positively related with the number of branches per plant as it was high at the lowest seed rate and low at the highest seed rate. Tuncturk et al. (2005) demonstrated that, the highest number of pods per plant (14.65) was obtained from the lowest seed rate $\left(5 \mathrm{~kg} \mathrm{ha}^{-1}\right)$ and the lowest value (9.48) from the highest seed rate (20 $\mathrm{kg} \mathrm{ha}^{-1}$ ). However, Roussis et al. (2017) got insignificant results although increased seed rate reduced the number of pods per plant.

Unlike the other yield and yield components discussed, neither the seed rate nor the inter-row spacing treatments influenced the number of seeds per pod (Table 2), which was supported by the results of Roussis et al. (2017) who also got non-significant results. Nevertheless, Tuncturk et al. (2005) found the highest number of seeds 
per pod (71.12) at $10 \mathrm{~kg} \mathrm{ha}^{-1}$ seed rate and the lowest (66.45) at $20 \mathrm{~kg} \mathrm{ha}^{-1}$ however significant differences were not obtained between the 10 and $15 \mathrm{~kg} \mathrm{ha}^{-1}$ seed rates.

Seed rate significantly influenced the seed yield per hectare, nevertheless the inter-row spacing did not (Table 2). The seed yield increased in the range of 462 to $636 \mathrm{~kg} \mathrm{ha}^{-1}$ when the seed rate increased from 5 to $20 \mathrm{~kg} \mathrm{ha}^{-1}$. The highest average seed yield $\left(636 \mathrm{~kg} \mathrm{ha}^{-1}\right)$ was obtained at the highest seed rate $\left(20 \mathrm{~kg} \mathrm{ha}^{-1}\right)$ and the lowest (462 $\mathrm{kg} \mathrm{ha}^{-1}$ ) was obtained from the lowest seed rate $\left(5 \mathrm{~kg} \mathrm{ha}^{-1}\right)$. According to Tuncturk et al. (2005), a significant increment in seed yield of black cumin was obtained as seed rate increased from 5 to $15 \mathrm{~kg} \mathrm{ha}^{-1}$ then declined when reached at $20 \mathrm{~kg} \mathrm{ha}^{-1}$. However, the highest $\left(7.01 \mathrm{q} \mathrm{ha}^{-1}\right)$ and the lowest $\left(3.64 \mathrm{q} \mathrm{ha}^{-1}\right)$ average yields were obtained from $15 \mathrm{~kg} \mathrm{ha}^{-1}$ and $5 \mathrm{~kg} \mathrm{ha}^{-1}$ seed rate applications respectively. Our results were also in agreement with what was obtained by Akintoye et al. (2009) in that, the yield per unit area tends to increase as plant density (seed rate) increases up to a point and then declines. Although a declining yield trend was not experienced in our findings, there was a room to increase the yield with increasing the seed rates until the optimum point was reached (Figure 2). Kizil \& Toncer (2005) studied the effect of row spacing on seed yield and yield components of black cumin and found similar results on plant height, seed per capsule (pod) and seed yield per hectare with the present study. However, in contrary to our findings, Kizil \& Toncer (2005) found that, branches per plant, capsule per plant, and seed yield per plant were significantly affected by row spacing treatments which varied from 20 to $50 \mathrm{~cm}$.

Norman (1992) reported that increasing plant density does not affect individual plants if the plant density is below the level at which competition occurs between plants. This finding was reflected in our results of seed yield per plant although it was not significant. Increasing neither the seed rate nor the inter-row spacing affected the seed yield per plant (Table 2) for the reason that the plant densities studied were below the level for the competition to occur between plants. This phenomenon was also observed for the seed yield per hectare in that although increasing seed rates increased the seed yield per hectare, the magnitude of the plant densities used did not reach at a level to create maximum competition, which could have been depicted by a point of return (Figure 2). Besides, although the number of pods per plant was significantly affected by the seed rate, its contribution to the seed yield per plant was not observed as it decreased with increasing the seed rate. The contribution of the number of seeds per pod rather affected the seed yield per hectare as it showed increasing trend with increasing seed rate (Table 2).

Abdolrahimi et al. (2012) studied the effect of inter and intra-row spacing on three black cumin varieties and found that, both factors affected different growth and yield parameters. Compared with our findings, the narrow inter-row spacing $(20 \mathrm{~cm})$ was found to be the best as it yielded better results and the yield particularly reduced when the raw spacing increased to $40 \mathrm{~cm}$. Nevertheless, contradictory results obtained by Koli (2013), who did research on the influence of plant spacing on two black cumin varieties, showed increasing yield of black cumin varieties with increasing inter-row spacing from 15 to $25 \mathrm{~cm}$. However, it did not show whether the yield increment would continue or not at wider row spacing beyond $25 \mathrm{~cm}$. Giridhar et al. (2017) studied several growth, yield and yield components of black cumin in response to different plant densities. In accordance with the findings of the present study, many of the parameters including branches per plant, capsules per plant, and seed yield were significantly influenced by the plant densities. However, the results on parameters like days to emergence, plant height, number of seed per capsule and seed yield per plant were not in agreement with that of the present study.

In general terms, Mazumder et al. (2007) stated that plants grown under normal spacing could have optimum population density per unit area which provides optimum conditions for luxuriant crop growth and better plant canopy area due to maximum light interception, photosynthetic activity, assimilation and accumulation of more photosynthates into plant system and hence produce more seed yield with best quality traits. Besides, Alizadeh \& Koucheki (1995) added that, at optimum plant density, all environmental parameters such as water, air, light, and soil are fully exploited by plants and at the same time competitions are minimized. Due to the fact that, at a higher seed rate and narrow inter-row spacing (or high plant density) plants compete for light and prefer to proportionate the available soil nutrients, moisture and of course the photosynthate to vertical growth than lateral growth. However, at lower seed rates and wider inter-row spacing, plants rather allocate more food/or energy for lateral growth than height due to availability of enough space, and sufficient light interception. As a result of these, plant growth traits such as plant height, branches per plant, pods per plant, and seed per pod and ultimately seed yield per unit area could vary with different row spacing and seed rates (plant densities). However, the genotype, environmental conditions and agricultural practices also have influence on the variations in results between similar studies (Tuncturk et al. 2005).

\section{Conclusions and recommendations}

The interaction effect of seed rate and inter-row spacing was not found significant for all growth and yield contributing parameters including seed yield itself. However, the main effect of the individual factors was significant on most of the parameters studied. Statistically, significant variations were obtained on growth and seed yield attributes of black cumin with increasing seed rates. Increasing the seed rates from $5 \mathrm{~kg} \mathrm{ha}^{-1}$ to $20 \mathrm{~kg}$ $\mathrm{ha}^{-1}$ resulted in increased in average black cumin seed yield in the range of $462 \mathrm{~kg} \mathrm{ha}^{-1}$ to $636 \mathrm{~kg} \mathrm{ha}^{-1}$. Nevertheless, the inter-row spacing of $20 \mathrm{~cm}, 30 \mathrm{~cm}$ and $40 \mathrm{~cm}$ caused statistically non-significant differences for most of the 
growth and yield related traits except for days to emergence and plant height. Although increasing seed rate showed increasing trend of seed yield with no point of return, as a recommendation, $15 \mathrm{~kg} \mathrm{ha}^{-1}$ seed rate combined with 30 $\mathrm{cm}$ inter-row spacing could be used for black cumin production as most yield and yield related traits showed reasonable performances and were not statistically different from the maximum seed rate $\left(20 \mathrm{~kg} \mathrm{ha}^{-1}\right)$ and interrow spacing $(40 \mathrm{~cm})$. However, further research needs to be undertaken in different black cumin producing areas of the country on recent varieties if any, to achieve the optimum seed rate and inter-row spacing with information related to cost of production for better recommendation.

\section{Acknowledgments}

The authors would like to express their profound gratitude and sincere regards to Ethiopian Institute of Agricultural Research (EIAR) for fully financing the study.

\section{References}

Abayneh, E., Demeke, T., Gebeyehu, B. \& Kebede, A. (2003), "Soil of Kulumsa Agricultural Research Center", National Soil Research Center (NSRC), Soil survey and land evaluation, Technical Paper No.76.

Abdolrahimi, B., Mehdikhani, P. \& Hasanzadeh, G.T. (2012), "The effect of harvest index, yield and yield components of three varieties of black seed (Nigella sativa) in different planting densities", International Journal of AgriScience, 2(1), 93 - 101.

Adam A. (2006), "Evaluation of Ethiopian black cumin (Nigella sativa L.) Landraces for agronomic characters and oil content at Adet and Woreta, North-West Ethiopia", MSc Thesis, Alemaya University of Agriculture, Ethiopia.

Akintoye, H.A, Kintomo, A.A. \& Adekunle, A.A. (2009), "Yield and fruit quality of watermelon in response to plant population", International Journal of Vegetable Science, 15(4), 369 - 380.

Ali, B.H. \& Blunden, G. (2003), "Pharmacological and toxicological properties of Nigella sativa", Phytotherapy Research, 17, 299 - 305.

Alizadeh, A. \& Koucheki, A. (1995), "Farming principles in arid zones", Astan-e Qods-e Razavi Press, (In Persian)

Arici, M., Sagdic, O. \& Gecgel, U. (2005), "Antibacterial effect of Turkish black cumin (Nigella sativa L.) oils", Grasas y Aceites, 56 (4), 259 - 262.

Ashraf, M. \& Orooj, A. (2006), "Salt stress effects on growth, ion accumulation and seed oil concentration in an arid zone traditional medicinal plant ajowan (Trachypermum ammi L. Sprague)", Journal of Arid Environment, 64, 209 - 220.

Black, M., Bewley, D. \& Halmer (2005), “The Encyclopedia of seed science, technology and uses”, Wallingford, $\mathrm{CAB}$

Datta, S., Sharanghi, A.B., Pariari, A. \& Chatterjee, R.R. (2001), "Prospect of minor spices cultivation in West Bengal", Paper presented in VIII State Science Congress, $28^{\text {th }}$ Feb - $2^{\text {nd }}$ March, 2001, Kalyyani Publisher, West Bangal, India.

EIC (Ethiopian Investment Commission) (2016), "Investment opportunity Profile for Spice Processing in Ethiopia", Addis Ababa, https://www.investethiopia.gov.et, Accessed on 14 October 2020.

Ermias A., Addis A., \& Teshom, M. (2015), "Adaptability Study of Black Cumin (Nigella sativa L.) Varieties in the Mid and High Land Areas of Kaffa Zone, South West Ethiopia", Agriculture, Forestry and Fisheries, 4(1), $14-17$

Getinet, A.A., Adam, B., Daniel, Asmamaw, Y., Dereje, R. \& Fekadu, G. (2010), "Black cumin (Nigella sativa L.) Varieties 'Aden' and 'Dershaye'", In: Registration of plant varieties, Ethiopian Journal of Agricultural Sciences, 20, 179 -194.

Giridhar, K., Sathyanarayana, G.R., Surya, S.K., Lalitha, A.K. \& Sivasankar, A. (2017), "Influence of Sowing Window and Plant Density on Growth, Phenology, Yield and Quality of Nigella sativa L. in Coastal Humid Tropic", International Journal of Current Microbiology and Applied Sciences, 6(9), 499 - 512.

Hammo, Y.H. (2008), "Effect of high levels of nitrogen and phosphorus fertilizer on growth, yield and yield components of Nigella sativa L.", Mesopotamia Journal of Agriculture, 36, 2 -11.

Hedberge, I., Edwards, S. \& Sileshi, N. (2003), "Flora of Ethiopia and Eriteria, Apiaceae to Dipsaceae", The Natural Herbarium, Addis Ababa University, Addis Ababa and Uppsala.

Kifelew, H., Fikre, D., Luleseged, T., Bekele, D., Mitiku, H. \& Getachew, W. (2017), "Seed Spices Production Guideline. Technical Research Report", Ethiopian Institute of Agricultural Research (EIAR), Addis Ababa.

Kizıl, S. (2002), "The effects of different seed rates of selected coriander (Coriandrum sativum L.) lines on yield, yield components and essential oil rate", Turkish Journal of Field Crops, 7, 99 -105.

Kizil, S. \& Toncer, O. (2005), "Effect of raw spacing on seed yield, yield components, fatty oil and essential oil of Nigella sativa L.", Crop Research, 30(1), 107 -112.

Kokdil, G., Ozbilgin, B. \& Uygun, C. (2006), "Morphology and stem anatomy of some species of genus Nigella L. in Turkey”, Journal of Faculty of Pharmacy of Ankara University, 35(1), 19 - 41. 
Kokdil, G., Delialioglu, N., Ozbilgin, B. \& Emekdas, G. (2005), “Antibacterial Activity Screening of Nigella L. Species Growing in Turkey", Journal of Faculty of Pharmacy of Ankara University, 34(3), 183-190.

Koli, S.A. (2013), "Effect of variety and plant spacing on seed yield and yield attributes of black cumin (Nigella sativa L.)", Msc Thesis, Sher-e-Bangla Agricultural University, Dhaka.

Mazumder, S.N., Moninuzzaman, M., Rahman, S.M.M. \& Basak, N.C. (2007), "Influence of support systems and spacing on hyacinth bean production in the eastern hilly area of Bangladesh", Legume Research, 30(1), 1 - 9.

Ministry of Agriculture and Natural Resources (MoANR) (2009), "Plant Variety Release, Protection and Seed Quality Control Directorate Report", Addis Ababa, Ethiopia, 19, 242 - 244.

Norman, J.C. (1992), "Tropical vegetable crops", Arthur, H., Stock well Limited, London.

Orgut (2007), "Market Assessment Study, Ethiopian Nile Irrigation and Drainage Project, Main Report and Annexes", Ministry Of Water Resources, Addis Ababa.

Roussis, I., Travlos, I., Bilalis, D. \& Kakabouki, I. (2017), "Influence of Seed rates and Fertilization on Yield and Yield Components of Nigella sativa L. Cultivated under Mediterranean Semi-Arid conditions", AgroLife Scientific Journal, 6(1), 218 - 223.

Samima, S., Bhabani, D., Bankim, C.R., Ganesh, D. \& Md Banaz, A. (2018), "Effect of Date of Sowing on Productivity of Black Cumin", International Journal of Current Microbiology and Applied Sciences, 7(1), $1796-1800$.

SAS (Statistical Analysis System) software (2009), "Version 9.2. Inst. Cary North Carolina", USA.

Shewaye L. (2011), "Antifungal Substances from Essential Oils", MSc Thesis, Addis Ababa University, Ethiopia.

Toncer, O. \& Kizil, S. (2004), "Effect of Seed Rate on Agronomic and Technologic Characters of Nigella sativa L.", International Journal of Agriculture \& Biology, 6(3), 529 - 532.

Tuncturk, M., Ekin, Z. \& Turkozu, D. (2005), "Response of Black Cumin (Nigella sativa L.) to Different Seed Rates, Growth, Yield Components and Essential Oil Content", Journal of Agronomy, 4(3), 216 - 219.

Zigyalew G. (2020), "Status of Black Cumin (Nigella Sativa L.) Research and Production in Ethiopia”, A Review, International Journal of Forestry and Horticulture, 6(3), 20 - 29. 